УДК 903.4; 903.2; 551.8

https://doi.org/10.24852/2587-6112.2021.3.298.306

\title{
THE ARCHAEOLOGICAL SITE OF PALMYRA BEFORE AND AFTER THE WAR IN SYRIA
}

\section{(C) 2021 Sh. AlAsaad}

In the article there is example of the ancient Syrian city of Palmyra, the article examines the problems of loss and preservation of the world historical, cultural, archaeological and architectural heritage in the context of modern local military conflicts. During the periods of Antiquity and the middle Ages, a complex of monuments, unique in composition and size, was formed here, combining ancient Eastern, Roman, Byzantine and Arab elements. During the ongoing acute armed conflict in Syria, because of the purposeful actions of religious terrorist-extremist organizations, defined by the author as an "international historian of cultural terrorism", he suffered catastrophic damage. An analysis of the scale of this damage, as well as the effectiveness of the efforts of the Syrian authorities, international organizations and the world community, shows that the preservation and restoration of Palmyra's heritage is possible because of painstaking, complex, joint work of all interested parties. Thus, the example of Palmyra showed the military conflicts in the Middle East, along with the actual destruction of entire states, the death of a huge number of people, the economic crisis, millions of refugees, was an attack on the heritage of ancient civilizations, which caused unprecedented loss of world cultural heritage in modern history. Now the world community faces a long and comprehensive joint effort to determine the damage, restore, and prevent further destruction and looting of the cultural heritage of Palmyra and Syria.

Keyword: Historical and archaeological heritage, Palmyra, Monuments, The war in Syria, Terrorism, UNESCO.

\section{АРХЕОЛОГИЧЕСКИЕ РАСКОПКИ ПАЛЬМИРЫ ДО И ПОСЛЕ ВОЙНЫ В СИРИИ}

\section{Ш. АлАсаад}

В статье на примере древнего сирийского города Пальмира рассматриваются проблемы утраты и сохранения всемирного историко-культурного, археологического и архитектурного наследия в условиях современных локальных военных конфликтов. В периоды Античности и Средневековья здесь сформировался уникальный по составу и размерам комплекс памятников, сочетающий древневосточные, римские, византийские и арабские элементы. В ходе продолжающегося острого вооруженного конфликта в Сирии, в результате целенаправленных действий религиозных террористическо-экстремистских организаций, определяемых автором как «международный историко-культурный терроризм», ему был нанесен катастрофический ущерб. Анализ масштабов этого ущерба, а также эффективности усилий сирийских властей, международных организаций и мирового сообщества, показывает, что сохранение и восстановление наследия Пальмиры возможно в результате кропотливой, сложной, совместной работы всех заинтересованных сторон. Таким образом, пример Пальмиры показал, что последствием военных конфликтов на Ближнем Востоке, наряду с фактическим разрушением целых государств, гибелью огромного числа людей, кризисом экономики, миллионами беженцев, стала атака на наследие древнейших цивилизаций, вызвавшая беспрецедентные в новейшей истории потери мирового культурного наследия. Теперь мировому сообществу предстоят долгие и всеобъемлющие совместные усилия по определению ущерба, восстановлению, предотвращению дальнейшего разрушения и разграбления культурного наследия Пальмиры и Сирии.

Ключевые слова: историко-археологическое наследие, Пальмира, памятники, война в Сирии, терроризм, ЮНЕСКО.

The Syrian Desert (Al-Badiya) constitutes about a half of the area of the Syrian Arab Republic, stretching between the valley of the Euphrates River on the North and East, uplands and hills on the West, and being the continuation of the desert on the North up to the peninsula the Arab Dzhazira, and possessed the most substantial historical values which were created and remained since the Stone Age until the Islam period.
Palmyra is the most archaeologically significant area in the Syrian Desert sue to numerous artifacts, and its great history is closely connected with the name of queen Zenobia.

Palmyra is located in the center of the Syrian Desert approximately equally spaced from the Syrian cities (Al-Asaad, Kh. 1996, p. 26), and the water source (Efka spring) near the mountain pass became the geographical center 


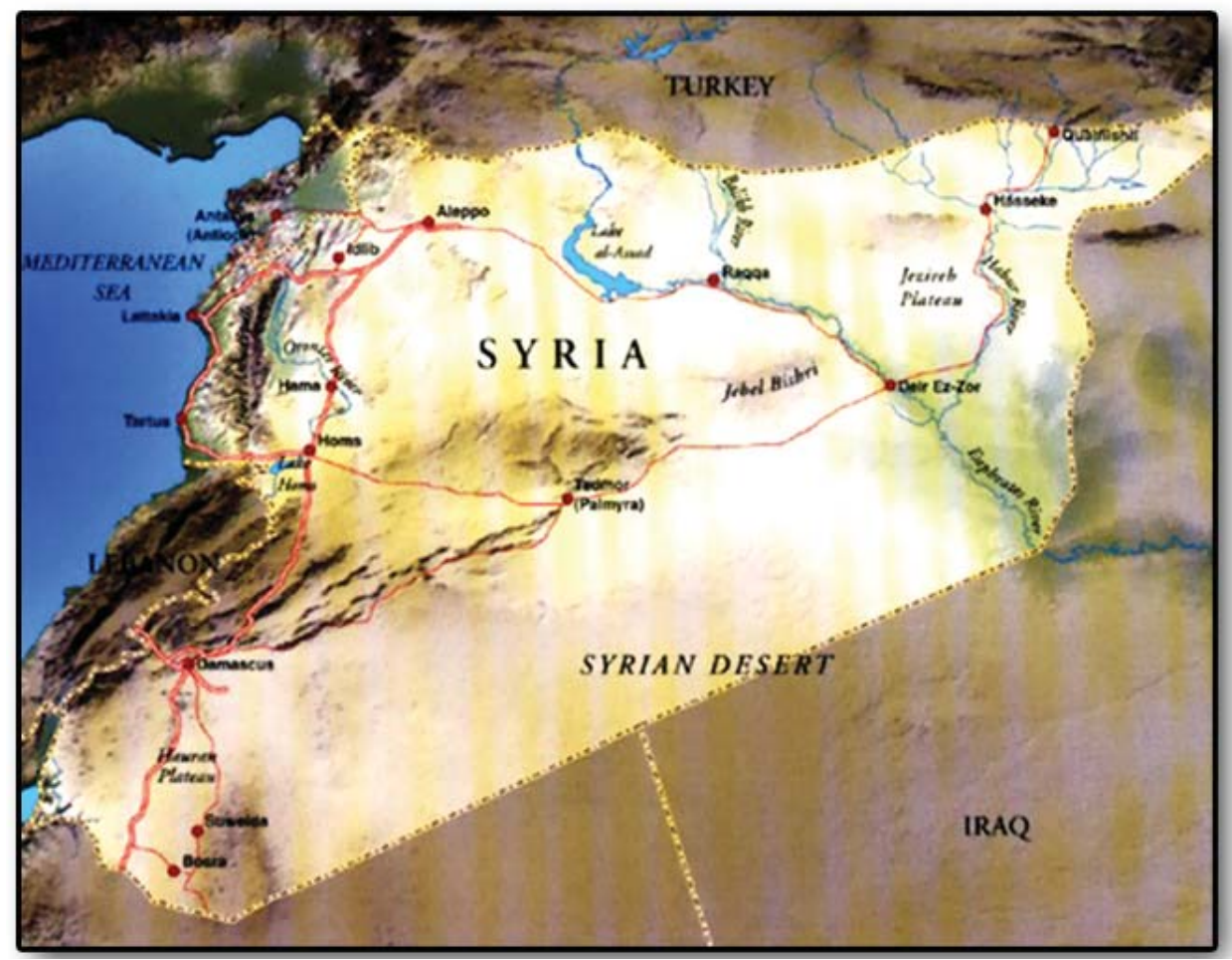

Fig. 1. The map of the Syrian Arab Republic

Рис. 1. Карта Сирийской Арабской Республики

of Palmyra (Al-Bunni A. 1978, p. 63). The city of Palmyra and its suburbs create an ideal opportunity for emerging human settlements from the most ancient times until today, owing to its geographical location from with a passage to the valley of Euphrates on the North (Madun, Mahomed Ali. 1995. P. 82).

The development and success if Palmyra are accounted for by the fact that it is located on the crossroads of the global trade routes beginning in China and India and passing through Iran, Iraq and Syria to east sea coast of the Mediterranean Sea (Soil, Hades, 2010, p. 153), and therefore is an important trade point between the countries of ancient Romans and Persians (Bagans, A., 1983, p. 16). It has endured the first attempt of capture by the Romans in 41, but was subject to the Roman emperor Adrian (117-138 AD) who gave the city the name of Palmira-Adriana (Starki, J., Al-Mnedzhed, Salah El-Dean, 1993, p. 12) (Adrianapolis) despite the fact that the city retained certain some financial, trade and military independence. Palmyra was also ruled by the emperor Septimus Severus in 193-211 AD, and his son Caracalla, in the period from 211 to 217 AD (Wood R. 1971. p. 125).

Palmyra was at the pinnacle of power throughout the first three centuries of our era, at the same time having become a strong kingdom, and its most famous rulers were the king Lutsy Odenat and his spouse Zenobia who governed on behalf of her younger son Vaballat and then became the queen of Palmyra and all East (Al-Asaad Kh., Ofakhvedberg H. 2006. 219 p. 160.).

She expanded the state borders, having annexed Egypt, Asia Minor and Anatoly. The Romans attacked the state, and a violent war broke out between them, which ended with the fall of Palmyra in 272 (Garf D.F., Gables C. 1998. p. 143-167.).

The fate of queen Zenobia has remained unknown, and the only information having reached is based on assumptions, in particular those demonstrating her capture and moving to Rome (Stars of Zagra... p. 298).

Christianity spread in Palmyra in the fourth century $\mathrm{AD}$ - during the rule of the emperor Theodosius, and temples of ancient gods were turned into churches.

Then, during the spread of Islam, Palmyra gained special importance due to its location between the Western and Eastern worlds.

The Arab ruler Khalid Bin Walid surrounded Palmyra in 636 during his known campaign through the Syrian Desert from Iraq to Yarmuk. He greeted the residents of Palmyra at fortifications of the city and proclaimed: "For the sake of Allah, residents of Palmyra, if you were friendly, then we would do you a favour and lead you to Allah's victory!", after which the residents made peace with him, and he left those among them who taught them the fundamentals of the new religion (Al-Hamoui Y. 1951. 831 p.). 


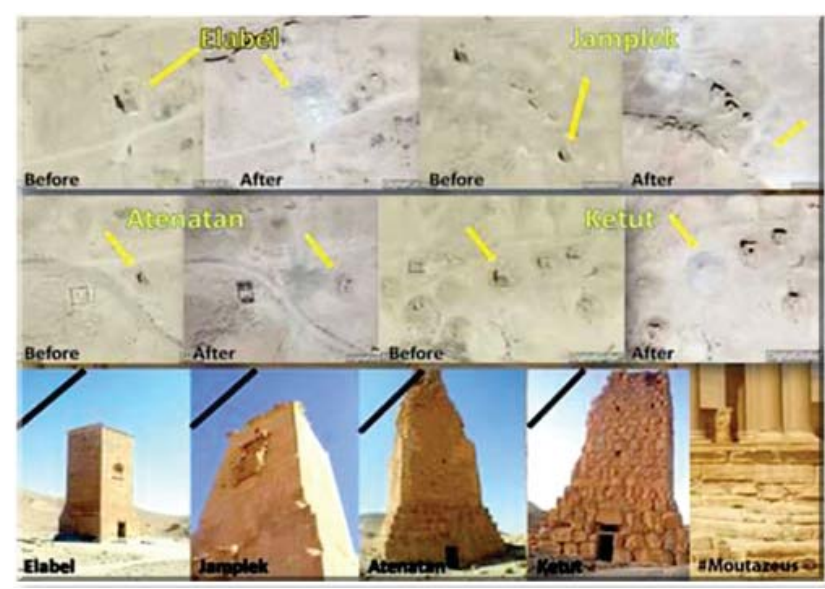

Fig. 2. Aerial photographs of the Tomb Towers published by Boston University

Рис. 2. Аэрофотоснимки башен Гробниц, опубликованные Бостонским университетом

Palmyra lost its significance as one of the main cities of the Levant countries when its rulers moved to Baghdad. Thus, it remained unknown up until the time when a contract was signed between Ayubs and Mamlukes (Al-Bakri. 1992. p. 177) when it became famous due to the new military fortifications, such as a citadel, and the Bel's temple turned into a fortified village protecting the state against crusader attacks (Al-Bunni A., Al-Assad, Kh. 2003. p. 93.).

City Design:

The residents of Palmyra were somewhat restricted by a construction project with a chess pattern which was widespread in the Ancient Rome period in Syria, and the houses of Palmyra residents first were located near Efka spring, but the city quickly expanded due to the prosperous economy and trade, and Palmyra turned into one of the richest deposits of antiquities, decorated by temples of ancient gods and the following presumably most significant buildings:

Temples:

1 - Bel's temple: Its construction is attributed to the first century AD, and it is generally dedicated to god Bel, and also a triad which include god Bel, Yarkhibol (god of the Sun) and Aglibol (god of the Moon). An extensive square yard with a 205-210 meter long fenced section is part of the temple (Abd-Alkhak S. 1996. p. 222-227.). In the center of the yard there is a temple with idols of the main god and the deities belonging to a triad, where an altar for sacrifices, a banquet room and a house of blessing are located. The temple is surrounded with a fence scalloped steps marking the entrance to the yard (Février, J.G.1931. p.97.2). The temple was turned into a strengthened village in the thirteenth century AD in the period when Salakheddin, Yusef the son of

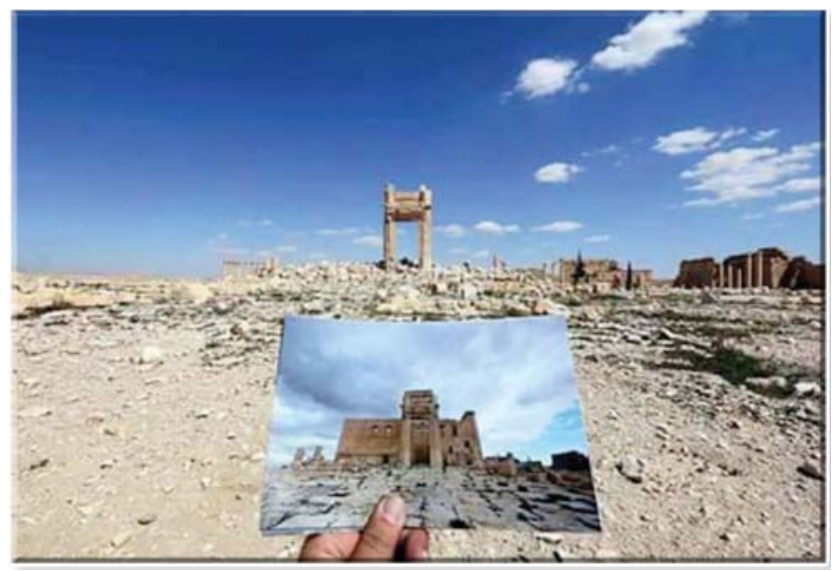

Fig.3. Destruction of the Temple of Bel

Рис. 3. Разрушение храма Бела

Feyruz ruled over Palmyra, and then became a mosque, and remained a mosque until 1929 (Abd-Alkhak S. 1996. P. 227).

2 - The temple of Nab: the temple is located to the west of Dlinnaya Street. Its construction took place in the second half of the first century $\mathrm{AD}$, and it is dedicated to the worship of god Nab, the son of god Bel (Al-Bunni A., Sleybi N. 1965. p. 41-49.). The building of the temple is to a certain extent similar to the building of the temple Bel's temple (Weigand, T. H. 1917, p. 115.).

3 - Baalshamin's temple: it is located in the northern area, and its history begins with the second century AD. This temple is devoted to the worship of god Baalshamin, the patron of heaven who was considered a god of a rain and thunder in Palmyra (Collar, P. 1957. P. 227-232.). The site of the temple consists of a sanctuary and two big yards, northern and southern, used as passages. The building of the temple is distinguished by the presence of a threshold before the sanctuary with six triangular columns (Al-Assad, Kh., Dagman, R., 1969, p.103.).

4 -Allat's Temple: The temple is located in the western area. His construction is also attributed to the second century AD, and it is dedicated to the worship of the goddess Allat (the Arabs' mother goddess and the goddess of war and peace). The building of the temple is similar to the buildings of other Palmyra temples, including a square yard, and an altar in the center which is preceded by a gallery with six columns. Before an altar, there is the main entrance in the form of a massive arch (Gavlikovsky M. 1983. p. 201-212.).

5 -Belkhammon and Manat's Temple: It is located on the western mountain over the location 

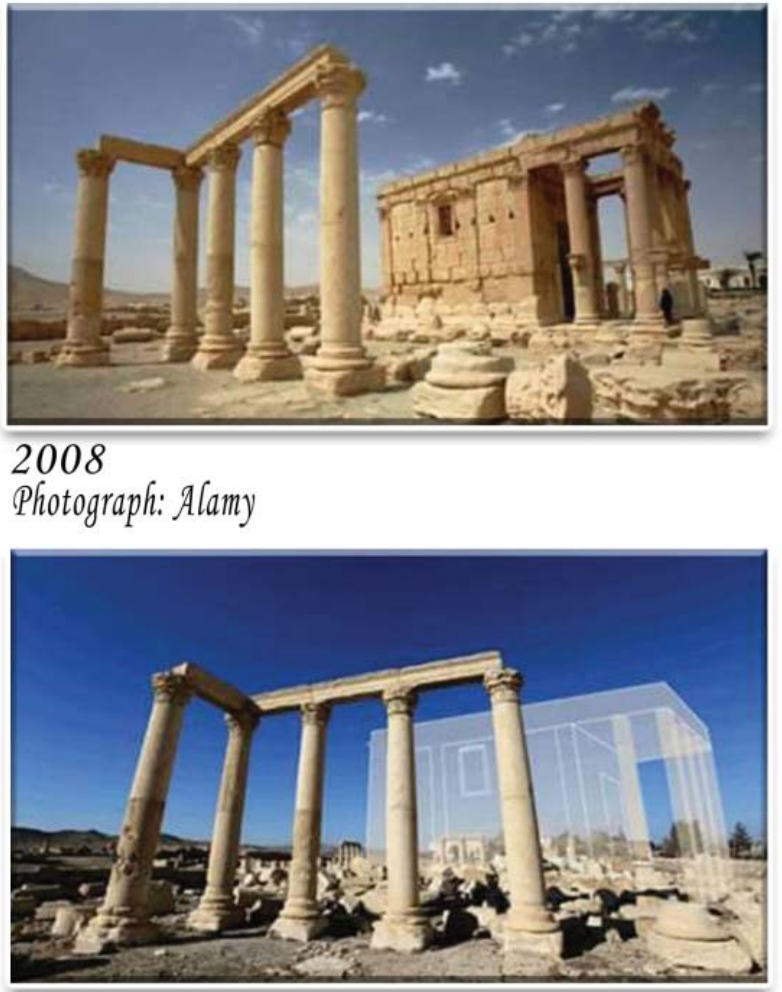

2016

Photograph: Joseph Eid/AFP/Getty Images

Fig.4. Temple of Baalshamin. Photos 2008 and 2016

Рис. 4. Храм Баалшамина. Фото 2008 и 2016 гг.

of the sacred spring Efka (Efka River), and it was constructed in $88 \mathrm{AD}$. The temple is devoted to the worship of the Canaanite god Balkhammon and the Arab goddess Manat (Al-Bunni, A., Al-Asaad, Kh. 2003. P. 75-76.).

6-Ars' Temple: The temple is located in the southern area in front of an agora and is devoted to the worship of god Ars, the Arab god of favour and the god of Palmira caravans (Al-Asaad Kh., Ofakhvedberg H. 2006. p. 119.).

Tombs:

The city residents referred to tombs as "rest houses" or "houses of eternity", as remains were deposited in them. Each family in Palmyra had own tomb. Families in Palmyra competed in decorating the tombs with relief ornaments on plaster or stone, and frescos. Each tomb had a water source for watering and cleaning after each process of burial and at visits. Tombs were closed with massive doors made of stone with carved ornaments (Sadorska A. 1996. p. 229.). Over the door, there was a window for lighting and airing of the tomb. Over the ceiling or over the window, an inscription was located with the name of the tomb's founder, and information about the members of his family and the history of the tomb. Along the internal walls of the tombs, ranks of crypts in the form of vertical rows were located. A sculptural image of the deceased was located on the front portion of the crypt. In the central part of the tomb, a sculptural group in the form of a funeral procession consisting of sculptures of the tomb's founder and the members of his family were located (Michalowski, K. 1982. p. 198.).

Three types of tombs have been revealed at the excavation site of Palmyra, including:

1 - Tombs in the form of towers: it the buildings in the form of a quadrangular tower located on the step bases, a tomb consisting of several floors connected with a stone ladder (Cantineau, J. 1992. p. 28). Tombs of this type were created since the first centuries $\mathrm{BC}$, and their construction improved in the first centuries AD. An example of this type of tombs is Elakhbel's tower (Saad Sh.To Khoums. 2006-2007. p. 23.).

2 -Underground tombs: this type of tombs was widespread in the second century AD, and each tomb was created according to the scheme in the form of the overturned letter $\mathrm{T}$, that is, there was a main wing and two wing branches. Underground tombs, as well as tower tombs, were richly decorated with carving on stone, and plaster. A bright example of this type of underground tombs is the crypt of Three Brothers (Ingholt H. 1935. p. 57-120.).

3 - Grave houses. This type of tombs appeared and was widespread also in the first century AD. As a rule, the building consists of one floor and has a beautiful entrance. The door is a stone monolith with plentiful quantity of the cut-out patterns. The building features an open yard surrounded with a covered yard with columns supporting the roof. Along the internal perimeter, there are steps, on which crypts and graves are constructed. Opposite, there is a sculptural group of a funeral procession in the form of figures of

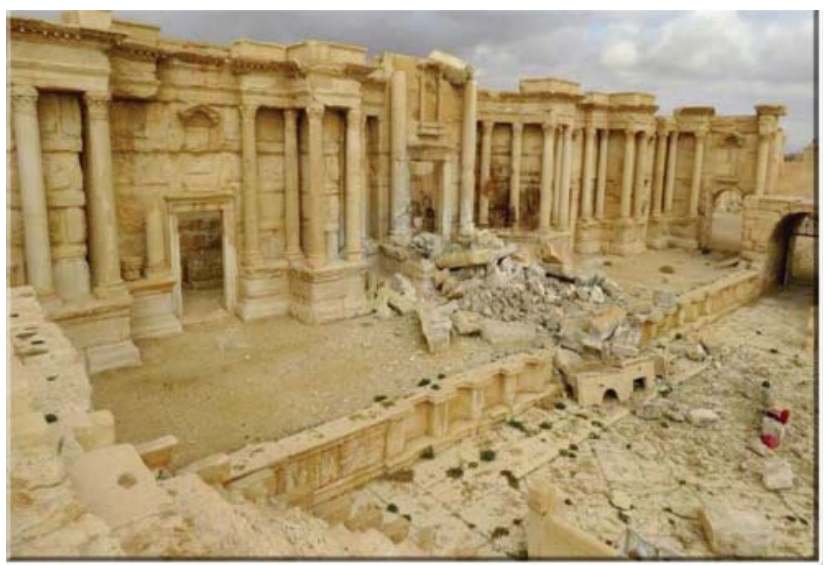

Fig. 5. Ruined roman theater

Рис. 5. Разрушенный римский театр 


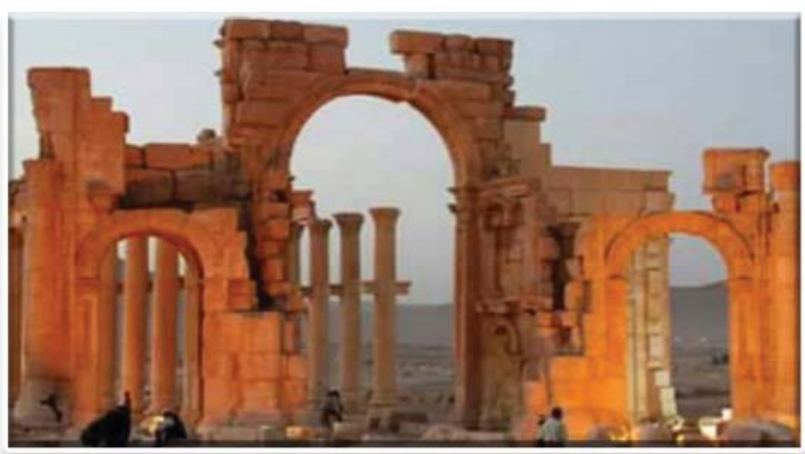

$12 \mathcal{N}$ ovember 2010

Photograph: Youssef Badawi/EPA

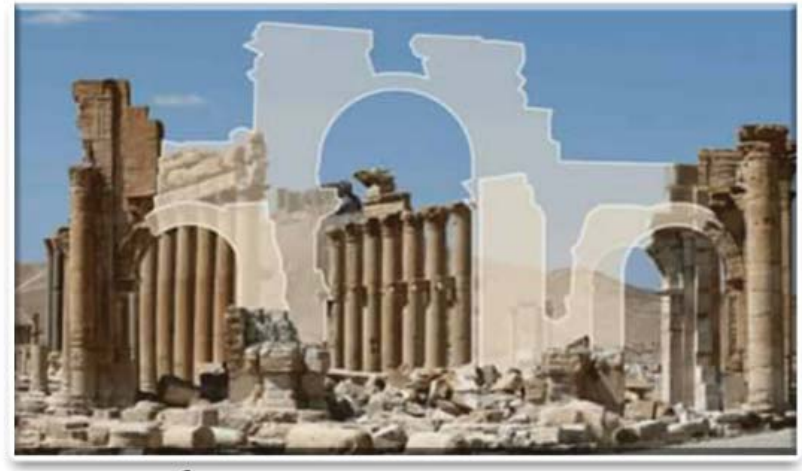

31 March2016

Photograph: Joseph Eid/afp/Getty

Fig. 6. Arch of Victory preserved after the war and view until 2010

Рис. 6. Арка Победы. После войны и вид до 2010 г.

the tomb's owner and the members of his family (Kolinye, A.Sch. 2005. P. 94.). In Palmyra, there are several grave houses, including Ailimi bin Zubeyda's tomb, and another grave house known as the White Palace (Kasr Al-Abyad) not far from Elakhbela tower. In addition to these tombs which were widespread in Palmyra in their various embodiments, there were also isolated sepulchral burials, among which is grave $\mathrm{G}$ discovered at an excavation by the Japanese group of researchers in east portion of the tombs in 2001. At the same time, the sizes of each separate isolated grave were in most cases $2.5 \times 1 \mathrm{~m}$. The internal area of the grave was decorated with stone bas-reliefs with cut-out ornaments. Deceased I was located in an earth grave in a coffin made from clay or wood, and over a grave was a plate decorated with a carved ornament, which ended on the top with a pyramid or a semicircle. The plate featured a figure of the deceased and his name cut out in stone (Al-Bunni, A. 1972. p. 42.).

\section{Pryamaya Street:}

This street starts from the main entrance to the Bel's temple and reaches the gate of Damascus, and four parts of this street can be allocated, limited to the main architectural sites:

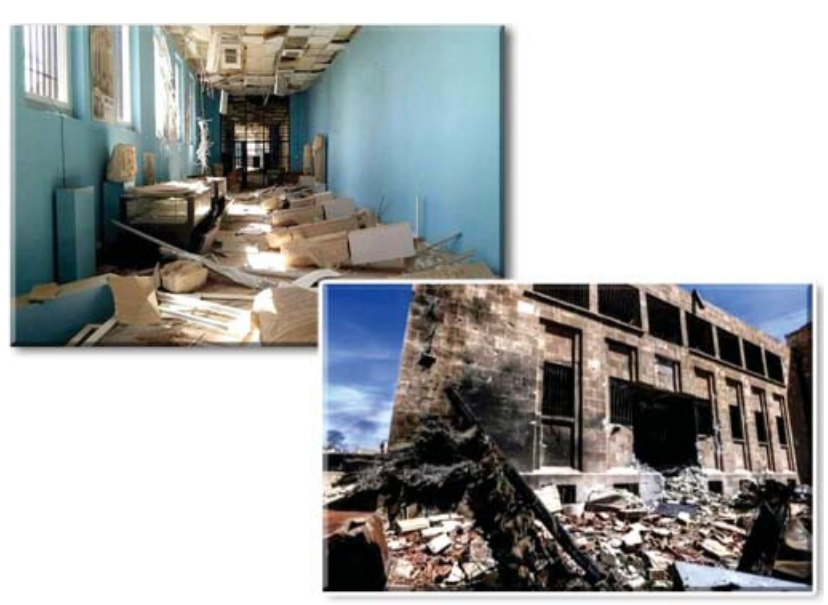

Fig. 7. Destructions in the National Museum of Palmira

Рис. 7. Разрушения в Национальном музее Пальмиры

- First part: stretches from the main entrance of the Bel's temple to the arch, and it is the widest of all parts of Pryamaya Street.

- Second part: stretches from the arch to the intersection (tetrapole).

- Third part: stretches from the intersection to the Funeral temple.

- Fourth part: stretches to the gate of Damascus (Ostras, A. 1969, p. 157.).

In a junction of the first and second part one can observe the skilful work of the architect of the corresponding historical period of Palmyra, who created the gate (Triumphal arch) to smoothen and hide the 28-degree turn of the street. The triumphal arch consists of three main entrances-arches with branches in the form of other entrances. The arches are richly decorated with various patterns, and the columns contained statues of famous city figures in their middle sections.

Intersection: This meeting place of two main city streets was known as the tetrapole. It is where roads to the north and to the south begin. The tetrapole consists of a base on which in four corners four pedestals tower, each of which bears four granite columns. Over colons there are Corinthian crowns, roofs and skillfully decorated carnices (Uitmar J. 1960. p. 327).

Theater: the theater was constructed in Palmyra in the form of a semicircle with a diameter of 20 meters surrounded with amphitheater rows, 13 of which have remained, and it possibly featured a top floor. In front of the orchestra there is an actor's stage dimensioned 48 meters in length and 10 meters in width (photo No. 15), limited to three with the statues of artists and equipped with two steps leading to the stage and two steps leading outside, and there were also 
three doors leading through with the arches decorated with patterns in three directions, behind which there are two rooms for actors and actors (Serig, H. 1940. P. 242.).

Square or the main city market which the Greeks called an "agora", and the Romans Vorum. This square was used for major city meetings (Starcky, J. p. 143-144. ) both in the times of peace and war, and also for commercial transactions. A square is a covered area of a square shape limited to a covered court yard with wooden ceilings. The area has eleven entrances for the ease of entering and leaving by visitors, and also accommodates the remains of a scene used for performances of speakers and announcement of commercial transactions. Between the court yard columns, supposedly, there were small rooms where trade caravans stopped, and the western corner of the square features a hall for meetings held by city governors (Ernest, W. 1992. p. 145-147).

In 1881 a stone stele was discovered in front of the southern renewed fence of the main entrance to the square, known under the name of "International Financial Law of Palmyra" (or Customs Tariff). Now the stele is deposited in the Hermitage Museum.

Diocletian's Camp: it was located behind city walls and served as a protective construction for Romans in the second century AD. The camp was arranged above the western portion of the modern city of Palmyra. The camp was most likely created as temporary structure and was used for certain military needs in order to implement the projects of the Roman emperors. After the fall of Palmyra in 273, the Roman emperor Diocletianus ordered to restore the camp and to rearrange it to accommodate a Roman garrison constantly deployed in Palmyra. Its architectural plan resembles that of a reinforced palace (Gerd, G. 1983, p. 68-69.).

\section{Citadel of Fakhr al-Din Al-Maani II:}

During the rule of the Ayubs, Palmyra was turned into a fortified fortified city to oppose the attacks of crusaders. The citadel served as a defensive structure in the 12-13 centuries AD, which is signified by the Ayubs ceramics found among the citadel ruins. The fortress was later used by the ruler of the Lebanese mountains Emir Fakhr al-Din Al-Maani II. During the construction of the fortress, stone boulders were widely applied to construct the fortifications and the top portions of the citadel. Also, the remains of foundations of a mobile bridge stretching from the top of the fortress to its southeast entrance have

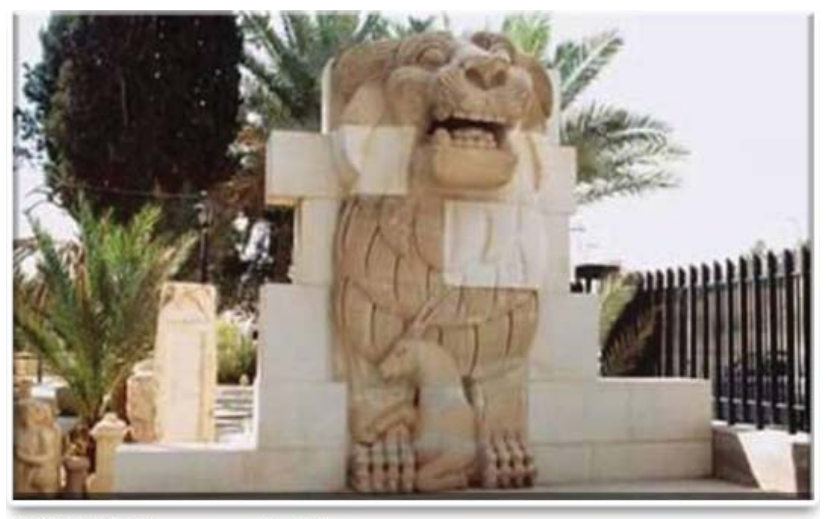

2008 Photograph: Alamy

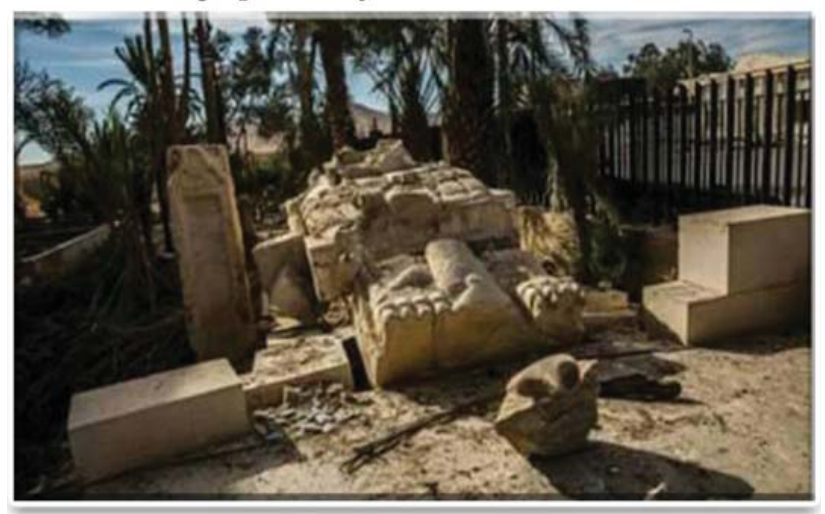

2016 Photograph: New York Time/Redux/Eyevine

Fig. 8. Statue of Assad Allat after the war and view before 2010

Рис.8. Статуя Асада Аллата после войны и вид до 2010 г.

remained until today (Mikhalovski , K. 19611962, p. 155-161.).

Baths: their creation is attributed to the time of queen Zenobia. Baths, as it was generally accepted, had three sections - cold, warm hot, and also an octagonal hall for resting which was used for storing clothes and undressing. In the centre of the hall there was an octagonal fountain for moistening of dry air, and a platform for sports activities and meetings was located nearby. The northwest corner of a bath accommodated a toilets (Gerd, G. 1983, p. 68-69).

\section{City walls:}

"Customs" walls made of clay and manure on a stone base are considered the oldest walls of the city. Today, one can examine the remains of the southwest corner of these walls located at the top of Mount Al-Muntar and near the tomb of Three Brothers. Subsequently, during the broad development of international trade, there was a need for construction of protective walls to defend the city. Palmyra was surrounded with fortifications with their external outlines in plan resembling a turtle figure and having a length of $6 \mathrm{~km}$. Walls took their actual shape during the rule of Odenat 


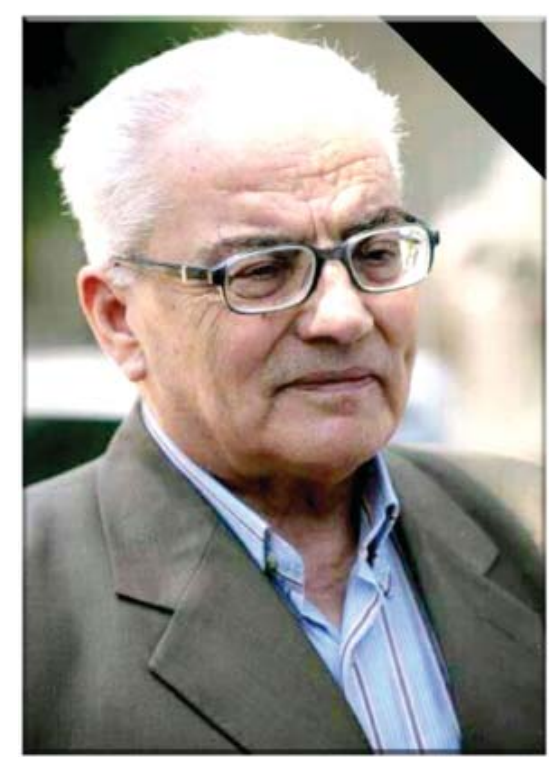

Fig. 9. The martyr archaeologist Khaled Al-Asaad

Рис. 9. Археолог-мученик Халид аль-Асад

and queen Zenobia (Al-Bunni, A., Al-Asaad, Kh. 2003, p. 82).

During the rule of emperor Justinian, round towers were built in city walls, and stones from the surrounding ruins of old buildings were used for their construction again. In the time of the Umayyads, a part of city walls was demolished. For preservation of ancient monuments in the historic centre of Palmyra, a part of city walls were reconstructed and restored during archaeological expeditions, in particular in their northern portion, starting from a point to the west of the museum, and ending at Diokletiana camp, and an approximate length of $2 \mathrm{~km}$ (Starcky, J. 1952. P. 11-67). During these activities, it was established that quadrangular towers were blind (had no passages), and semicircular towers were equipped with internal rooms with ladders leading up to the gate and to dart throwing sites. Some tomb towers located on the perimeter and near the walls used as protective constructions, especially during the rule of emperor Justinian. During the restoration of city walls, a set of inscriptions on stones was discovered, which were used in construction with no due account for their beauty and artistic value (Al-Bunni A. 1996. P. 263-267).

It should be noted that the ancient art in Syria in general and in Palmyra in particular has been subject to destruction and deterioration both in the aspect, and in respect of its significance, not only due to influence of the nature and the environment, but also due to the exclusively difficult conditions of the military and other nature, and after a war which lasted for seven years, the ISIL terrorist group entered the historic centre of ancient Palmyra and destroyed its major artifacts. At the same time, should be specified that the ancient city of Palmyra in general (including the Bel's Temple) has been included in the UNESCO World Heritage List since 1980. The UNESCO organization criticized the destructive activity of ISIL and called it a war crime committed with the purpose of destroying the most important symbol of historical heritage of Syria - its cultural diversity.

Below is a description of the state of historical monuments in the city of and the most grievous crimes committed by the terrorist group in this area:

1 - At the beginning of the period when the ISIL group began to control the city of Palmyra, it destroyed tomb towers.

2 - The major parts of the ancient Bel's temple were destroyed: members of the terrorist group blasted the base and thereby destroyed one of the most important monuments of architecture of the ancient city attributed to the first century AD.

3 - Baalshamin's temple, its foundation and columns were destroyed.

4 - Destruction of an amphitheater and theater: the satellite imagers feature the considerable destruction of a theater and the facade of an ancient Roman amphitheater, included in the World Heritage List, as a result of major explosion, and it is also visible that columns were undermined with use of explosives, and only two columns are presetly in place, whereas the main portion of the foundation was destroyed as confirmed by the presence of ruins around the theater. Destruction of the facade of a scene of an ancient Roman amphitheater and the fragments dispersed ross the entire area of the amphitheater are also noticeable.

5 - The Triumphal arch was destroyed: The triumphal arch is located at the beginning of Pryamaya Street and represents gate a with three entrances. In the top portion, the arch is decorated with geometrical and floral patterns. It was constructed by Septimus Severus in 193-211. The arch is arranged at an angle 30 degrees to Pryamaya Street, which is a rare solution in terms of architectural planning which connects the city with the square in front of the Bel's temple. The arch consists of three parts, of which the main entrance and the southern aperture (the left portion) were subject to most destruction, whereas the southern part (on the right) is in better condition. It was restored and newly constructed in the 1930s.

6 - The national museum of Palmyra has undergone major destruction by an ISIL terror- 
ist group whose members destroyed large funeral sculptures which the Head of Department of Antiquities and Museums could not move to Damascus due to their large volume. The major one of the sculptures is "A lion of Goddess Allat" which belongs to the temple of the goddess Allat (Athens) in the ancient city and was placed at the entrance to the museum of Palmyra on June 20,2015 . It consists of soft sandy stone, and its front portion features a lion leaning on its paws with its mouth open, and in its paws it holds a gazelle, fully confident in its safety. This monument was opened in 1977 by a Polish expedition, restoration has been carried out, and the sculpture was opened for display at museum walls. Its creation is attributed to the first century $\mathrm{BC}$, and there are no similar monuments in the world. The lion strikes viewers with the art and tangibility enclosed in the sculpture by its ancient creator. It should be noted that before the invasion into the historical part of Palmyra by the members of ISIL group, the employees of Department of
Management of Palmyra Antiquities covered the monument (which is dimensioned $3.5 \mathrm{~m}$ in height and $0.5 \mathrm{~m}$ in thickness, and weighs about 15 tons) with a metal protective structure, and encircled it with a fence made of sand bags to prevent its damaging in the course of possible explosions and military situations.

7 - The ancient citadel viewed from the Eastern side opposite to the centre of the ancient city has undergone considerable destruction, besides, and some of its parts and internal rooms have also been partially destroyed. Also, the ladder leading to it has been destroyed.

8 - The execution of a scientist specializing in antiquities, professor Khalid Al-Asaad, formerly the Director of Palmyra's Historical Heritage, by inhuman beheading on August 18, 2015. The execution happened on the square in front of the museum, then the body was carried away and hung on ancient columns which the scientist personally restored in the historic centre of Palmyra.

\section{REFERENCES}

Abd-Alkhak S. 1996. In TheArchaeological annals of Syria. The edition 42. P. 220-229.

Al-Asaad, Kh. 1996. In The Al-Amran magazine. edition 27-28. Damascus.

Al-Asaad Kh., Ofakhvedberg H. 2006. Zenobia is the queen Palmyra and the East. Damascus.

Al-Assad, Kh., Dagman, R. 1969. Restoration of the ruins of a sanctuary in Baalshamin's temple // the Syrian Arab Architecture, volume 19,

Al-Bakri. 1992. Ways and kingdoms. Part 2. Tunisia.

Al-Bunni A. 1996. In The Archaeological annals of Syria. The edition 42. P. 263-267.

Al-Bunni A. 1972. Art of Palmyra. V. 2. Damascus.

Al-Bunni A. 1978. Palmyra and palmirets. Damascus.

Al-Bunni A., Al-Assad, Kh. 2003. Ancient Palmyra, its Tourist History. edition 4.

Al-Bunni, A., Al-Asaad, Kh. 2003. Palmyra in the ancient time, in the history and in tourism. Damascus. P. 75-76.

Al-Bunni, A., Sleybi, N. 1965. In The Archaeological annals of Syria. The edition 15. Part 2. 41-49.

Al-Hamoui, Y. 1951. Almanac of the states. Part 1. Egypt. 831 p.

Bagans, Afif. 1983. Importance of archaeological opening when determining eras of historical development in Syria, the Syrian Arab relics of Antiquity, the edition 33, section 1.

Cantineau, J. 1992. Inventair des Inscriptions des Palmyre. IV. Byroth.

Collar, P. 1957. In The Archaeological annals of Syria. The edition 7. P. 227-232.

Ernest, W. 1992. Palmyrniens, la venise des sables. Paris.

Février, J. G. 1931. La religion des Palmyriens. Paris (in French).

Garf, D. F., Gables, C. 1998. Zenobia and Arabs. The Eastern Frontier of the Roman Empire// Proceeding of a colloquium held Ankara. Oxford. P. 143-167.

Gavlikovsky, M. 1983. In The Archaeological annals of Syria. The edition 33. Part 1. 201-212.

Gerd, G. 1983. Syria art, history, architecture.

Ingholt, H. 1935. Five Dated Tombs from Palmyra. Berytus.

Kolinye, A. Sch. 2005. In The Place and times to the 25 anniversary of archaeological researches in Syria. Damascus. P. 87-104.

Madun, Mahomed Ali. 1995. Civilized interactions on the silk way. Damascus.

Michalowski, K. 1982. Palmyra, fouill Polonaises. Varsovie. 
Mikhalovski K. 1961-1962. In The Archaeological annals of Syria. The edition 11-12. P. 155-161.

Ostras, A. 1969. In The Archaeological annals of Syria. The edition 19. Parts 1-2. P. 149-158.

Saad, Sh. 2006-2007. In The Archaeological annals of Syria. The edition 49-50. P. 16-31.

Sadorska, A. 1996. In The Archaeological annals of Syria. The edition 42. P. 220-231

Serig, H .1940. C.r.a.l. P. 242

Soil, Hades. 2010. Archeologists and the ancient cities, an excursion to the world of antiquities. T. 1.

Starcky, J. Inventaire. Op. cit. p. 143-144.

Starcky, J. 1952. Palmyra.

Starki, J., Al-Mnedzhed, Salah El-Dean. 1993. Palmyra is a bride of the desert. T. 1. Damascus.

Uitmar J. 1960. In Palmyra - history lessons. The Archaeological annals of Syria. The edition 10. P. 319-337

Weigand, T. H. 1917. Palmyra, Ergebnisse der expeditionenvon 1, Berlin.

Wood, R. 1971. Antiquities of Palmyra, in translation into Arabic Ibrahim Saad's language.

"Stars of Zagra", edition 92, p. 298.

\section{About the Author:}

AlAsaad Shaza. Damascus University. Damascus, 30621, Syrian Arab Republic; shathaasaad88@gmail. com

\section{Информация об авторе:}

АлАсаад Шаза. Дамасский университет (г. Дамаск, Сирийская Арабская Республика); shathaasaad88@gmail.com 